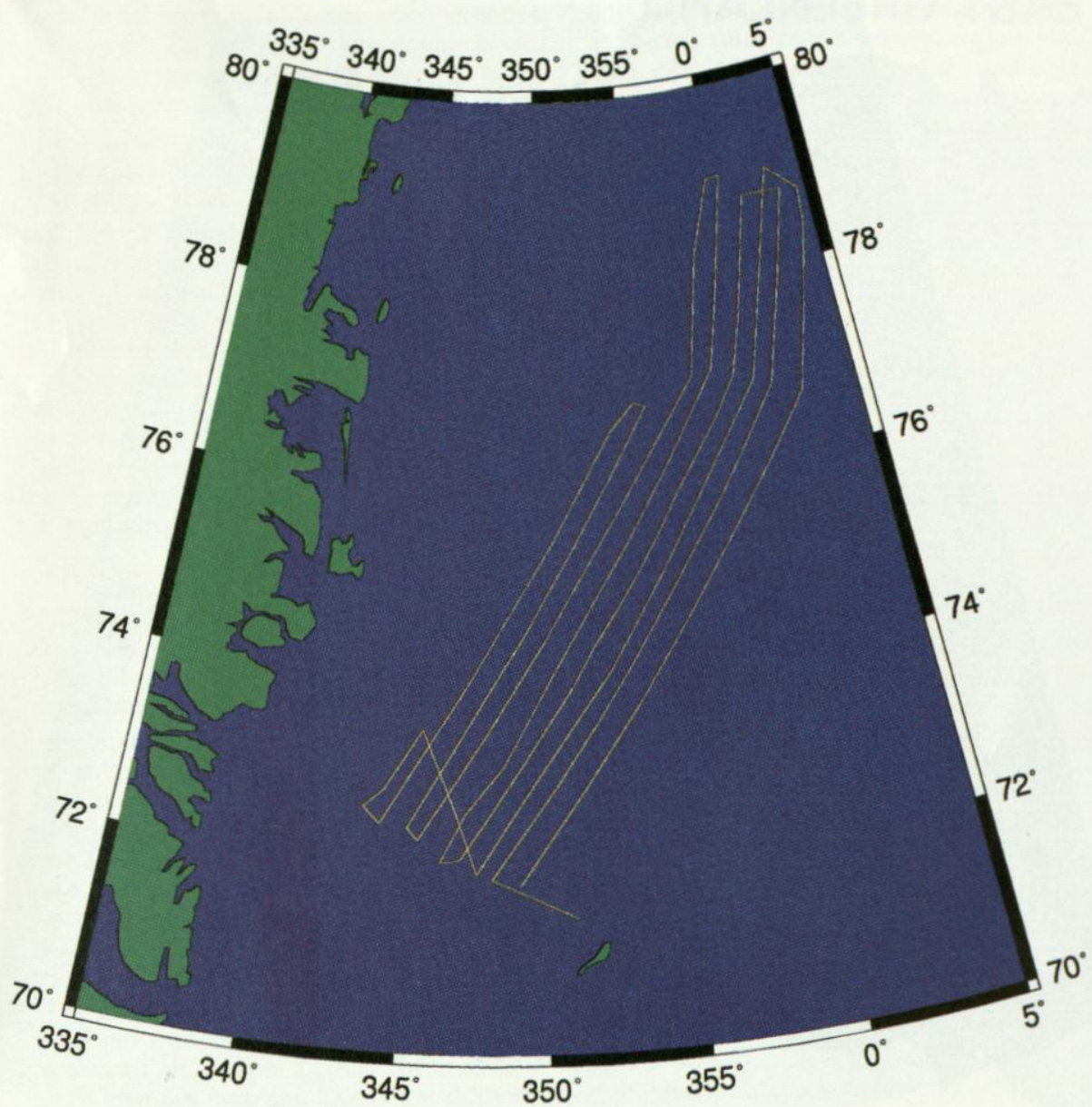

Fig. 1. Profile tracks of GLORIA sonographs along the east Greenland continental margin.

\title{
Polar Continental Margins: Studies off East Greenland
}

\section{J. Mienert, N. H. Kenyon, J. Thiede, and F.-J. Hollender}

The passive continental margin off east Greenland has been shaped by tectonic and sedimentary processes, and typical physiographic patterns have evolved over the past few million years under the influence of the late Cenozoic Northern Hemisphere glacia-

J. Mienert and J. Thiede, GEOMAR, Forschungszentrum für marine Geowissenschaften der ChristianAlbrechts-Universitaet zu Kiel, Wischhofstr. 1-3, 2300 Kiel, Germany, and Sonderforschungsbereich 313 (SFB 313) der Christian-Albrechts-Universitaet zu Kiel, Olshausenstr. 40-60, 2300 Kiel, Germany; N. H. Kenyon, Institute of Oceanographic Sciences (IOS), Brook Road, Wormley, Godalming, Surrey, GU8 5UB, U.K.; and F.-J. Hollender, Christian-Albrechts-Universitaet zu Kiel (address above)

Copyright 1993 by the American Geophysical Union 0096/3941/7420/93/225/\$01.00. mosaic of the data was made at a scale of $1: 375,000$. The base map was prepared with a polar stereographic projection having a standard parallel of $71^{\circ}$

The working area (Figure 2) is permanently covered by sea ice except during August to September when sea ice starts to melt and decay and its eastern margin relocates toward the shelf edge. Along this margin, southward flowing currents-such as the east Greenland Current (EGC) — carry cold water masses from the Arctic Ocean through the Denmark Strait into the North Atlantic. While these currents may cause a vigorous along-slope transport of sediments, the calving of glaciers from the East Greenland ice sheet and melt water may entrain large amounts of sediments, which are carried across the shelf and finally deposited in the deep sea by gravity flows. This highly dynamic system appears to be very sensitive to changes in ice-sheet extent and current activity, which are driven by fluctuations in Northern Hemisphere climate. Certainly, east Greenland is one of our best analogs for "glacial" polar margins because of the uninterrupted existence of the ice sheet. In contrast, the Norwegian margin was uplifted during past interglacials due to the recurrent decay of the continental ice sheets and the rebound of the lithosphere [Moerner, 1980]. Large-scale slumps occurred on this margin during interglacials, for instance, $6000-8000$ m.y. B.P. [Bugge et al., 1988]. Therefore, we may look to the seafloor off east Greenland as an analog for glacial times. Careful selec tion and accurate monitoring of seafloor environments in sensitive climatic regions can help determine what kind of depositional environment changes may take place and when.

One of the key locations of our survey was an area where cold water may cascade from the margin, which may add crucial information to the debate over the cascades' role in the down-slope transport of sediments. We set out to determine to what extent today's east Greenland margin provides a realistic analog for a glaciated European margin of the last glacial. Moreover, we hope to discover what differences, if any, can be detected between the present "warm house coast" of Norway versus the "ice house coast" of east Greenland. The results of this field program will permit comparisons with other studies, including the European-Science-Foundation-supported Polar North Atlantic Margins (PONAM) program and the European Commission MAST II-financed European North Atlantic Margin (ENAM) project. The survey will also contribute to the Ocean Drilling Program Leg 151, which is scheduled for 1993 [Ruddiman et. al., 1991]. ice sheets, current regimes, and sedimentary processes. In cooperation with IOS and the RV Livonia, a high-quality set of seafloor data has been produced. GLORIA's first survey of east Greenland's continental margin covered several $1000-\times 50-\mathrm{km}$-wide swaths (Figure 1) and yielded an impressive sidescan sonar image of the complete Greenland Basin and margin (about $250,000 \mathrm{~km}^{2}$ ). A

\section{Research Area}

The research area (Figure 2) encompassed Fram Strait, Boreas Basin, Greenland Basin, and a small basin just north of Jan Mayen. The overall basin morphology is de- 


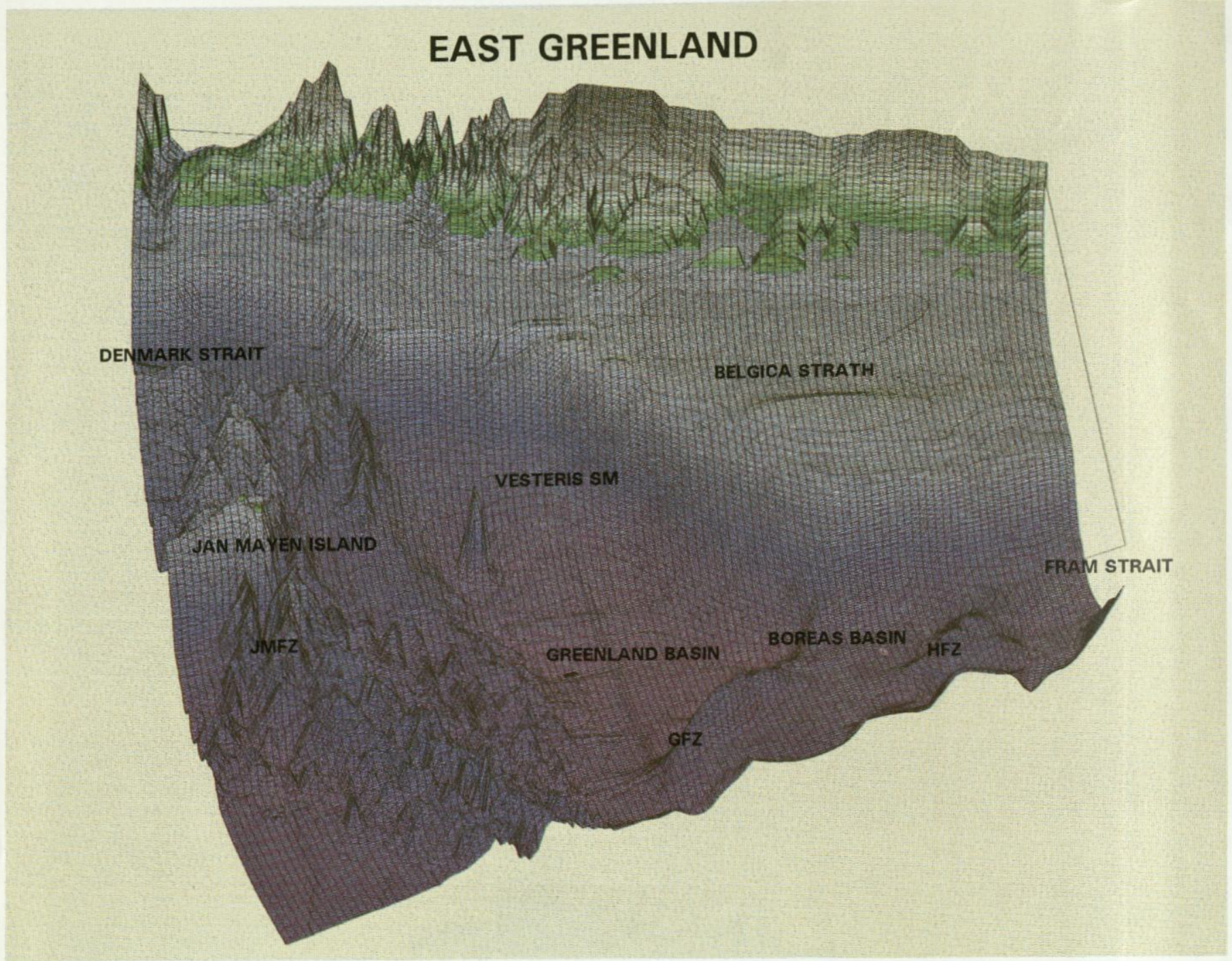

Fig. 2. Three-dimensional view of the east Greenland coastline, shelf, margin, and basins (SM, Seamount; IS, Island; HFZ, Hovgaard Fracture Zone; GFZ, Greenland Fracture Zone; JMFZ, Jan Mayen Frac ture Zone). The reader is looking from the Mid-Ocean Ridge toward east Greenland (northwest). While the Fram Strait connects the Greenland Sea with the Arctic Ocean, the Denmark Strait is a gateway between the Greenland Sea and the North Atlantic. termined by large fracture zones. All the major morphological changes in the area from north (Hovgaard Fracture Zone $=\mathrm{HFZ}$ ) to south (Jan Mayen Fracture Zone = JMFZ) were studied. In Greenland Basin, the large and isolated Vesteris Seamount [Hempel et. al., 1991; Henrich et al., 1992] is barely covered by sediments; it therefore appears to be young. In the east, we started close to the Mid-Ocean Ridge; in the west, sea ice created a natural limit to our survey. The east Greenland continental margin, one of the major target areas of the Ocean Drilling Program (legs 151 and 152) in 1993, is relevant to the debate over the response of ice cover and thermohaline circulation under various scenarios of global warming. An understanding of the sedimentary processes and their products can be achieved only when basic morphodynamic features of the ocean margin are known.

\section{Oceanic Basement Transform Ridges}

In general, the Greenland Sea basin structure is linked to major fracture zones and ridges [Vogt, 1986]. The transform ridges divide the area between Fram Strait and Jan Mayen into three basins: the small northwest-southeast oriented 3200-m deep Boreas Basin, the large northeast-southwest aligned 3600-m deep Greenland Basin, and the small east-west oriented 2400-m deep basin just north of Jan Mayen. There are flatsedimented tops on the transform ridges, like those seen on parts of the ridge to the north of Jan Mayen Fracture Zone and the Hovgaard Fracture Zone Ridge. These plateaus are at respective depths of about 500 1000 and $1400 \mathrm{~m}$. It is presumed that the plateaus were planed off near sea level, but it is not known whether they were planed at the ridge axis and subsided or if the plateaus were uplifted after they had started down the subsidence curve. The steep sides of the ridges are gullied, and gullies are especially well-developed around these submarine plateaus. They are almost parallel and north-south directed toward the currents.

These ridges clearly act as barriers to the southward flowing deep-water masses and influence their pathways.

\section{Oceanic Basin Sedimentary Features}

The three basins imaged during this survey are important to the understanding of glacially influenced margins. The sedimentary features found in these basins are strikingly different.

The Boreas Basin has a very uniform, medium- to low-level of backscatter apart from a single, weakly backscattering feature that looks like a channel. This channel is discontinuous and is thus believed to be inactive and perhaps filled by a fine-grained abandonment facies. There is an outstanding acoustic artifact on all of the sonographs across this basin that is believed to be interference fringes caused by multiple sound paths taken through the uppermost layers of soft sediment. This implies that there is some acoustic penetration into the seafloor and that the sediment layers have different acoustic properties and are fine-grained. The separation of the interference fringes increases progressively nearer to the Greenland Margin, which is believed to indicate an increase in layer thickness away from the 
margin [Huggett et al., 1992]. Characteristic circular patches of high backscatter are present at the margin, including some with positive relief. The patches are equidimensional and up to half-a-kilometer across, and they are thought to show some kind of gas venting that has produced features such as pockmarks, diapirism structures, and/or hard grounds.

The Greenland Basin, the largest and deepest basin along the east Greenland continental margin, shows a variety of backscattering, and the overall backscatter level is much higher than that of the Boreas Basin. The southeastern part of the basin, where the seafloor is isolated from any downslope gravity-driven sedimentation, is the only extensive area with a low level of uniform backscatter. Clearly, the rest of the basin is dominated by systems that feed in from the margin.

An area with a contrasting pattern of nonchannelized features exists in the northern part of the basin. This nonchannelized pattern occurs in front of a very long cross-shelf trough known as Belgica Strath. The shelf here is at its widest and appears to have been built over a long period by sedimentation from a glacier system that possibly occupied the cross-shelf trough. On the continental slope, we encountered changes from high backscatter at the upper slope to lower backscatter at intermediate depths (indicating a possible sediment wave field) to very low backscatter at the base of the slope. This depth-dependent zonation of backscatter is interrupted by downslope-trending stripes on the steeper slopes. These relationships give way near the foot of the slope to a pattern resembling regular bedforms with both transverse and longitudinal elements and below to a uniform and weakly backscattering zone. In the deepest regions, the backscattering strength increases and covers most of the seafloor. Down-slope changes in the depositional-erosional regime are implied by this zonation. The stripe feature is in keeping with the size of down-slope-trending features on the Norwegian margin that have been attributed to cold-water cascades [e.g., Vorren et al., 1989].

The south of Greenland Basin has four channel systems that resemble one another in most respects. The uppermost parts of these systems were not seen due to ice cover and distortions from water stratification that limit the range of the sonar. Below the steepest part of the slope, there is a welldeveloped tributary pattern of channels with a high order of branching. The branches join at angles and the channels are shallow and narrow. Below the junction of the tributaries, four single channels are observed that turn north and run toward the deepest part of the basin. They are narrow (up to about 2-km wide) and fairly straight. One sinuous channel is shown in Figure 3. To the side of the channels, regularly spaced bands of contrasting backscatter, believed to be sediment waves with wavelengths of 2 - to $3-\mathrm{km}$, exist. This common feature in deep-sea channelized systems is usually attributed to molding of the muddy overbank sediments by a process of flow stripping of the uppermost part of the channelized turbidity flows. The distal part of the channel systems have patterns that have been attributed elsewhere [Belder- son et al., 1984] to the deposition of sandy lobes. There is a braid-like pattern of higher backscattering, elongated features that are pointed at either end. They are separated by narrow, low-backscattering features that are probably very shallow channels. These channelized deposition systems are similar to those of the glaciated margin in the Gulf of Alaska as mapped by GLORIA side-scan sonar. Whether the down-slope sedimentation is currently active needs to be determined by seafloor sampling.

The third and smallest basin is nonchannelized. It connects the large Greenland $\mathrm{Ba}$ sin to the Denmark Strait in the south, one of the most important oceanographic gateways for North Atlantic deep-water flow. Like the Boreas Basin, it shows no obvious pattern of sediment input from the shelf. Surprisingly, there are only a few signs on the long-range sonographs of along-slope processes apart from some possible mud waves near the ridge, north of the Jan Mayen Fracture Zone.

Why are there major differences in sedimentation along this glaciated margin? We suggest that since the Boreas Basin has a permanently sea-ice covered continental margin where down-slope entrainment would not take place, it is dominated by vertical settling through the water column and deep-current processes rather than by downslope sedimentation.

\section{Conclusions}

Based on the preliminary interpretation of the GLORIA sonographs we conclude that

- little direct evidence for along-slope

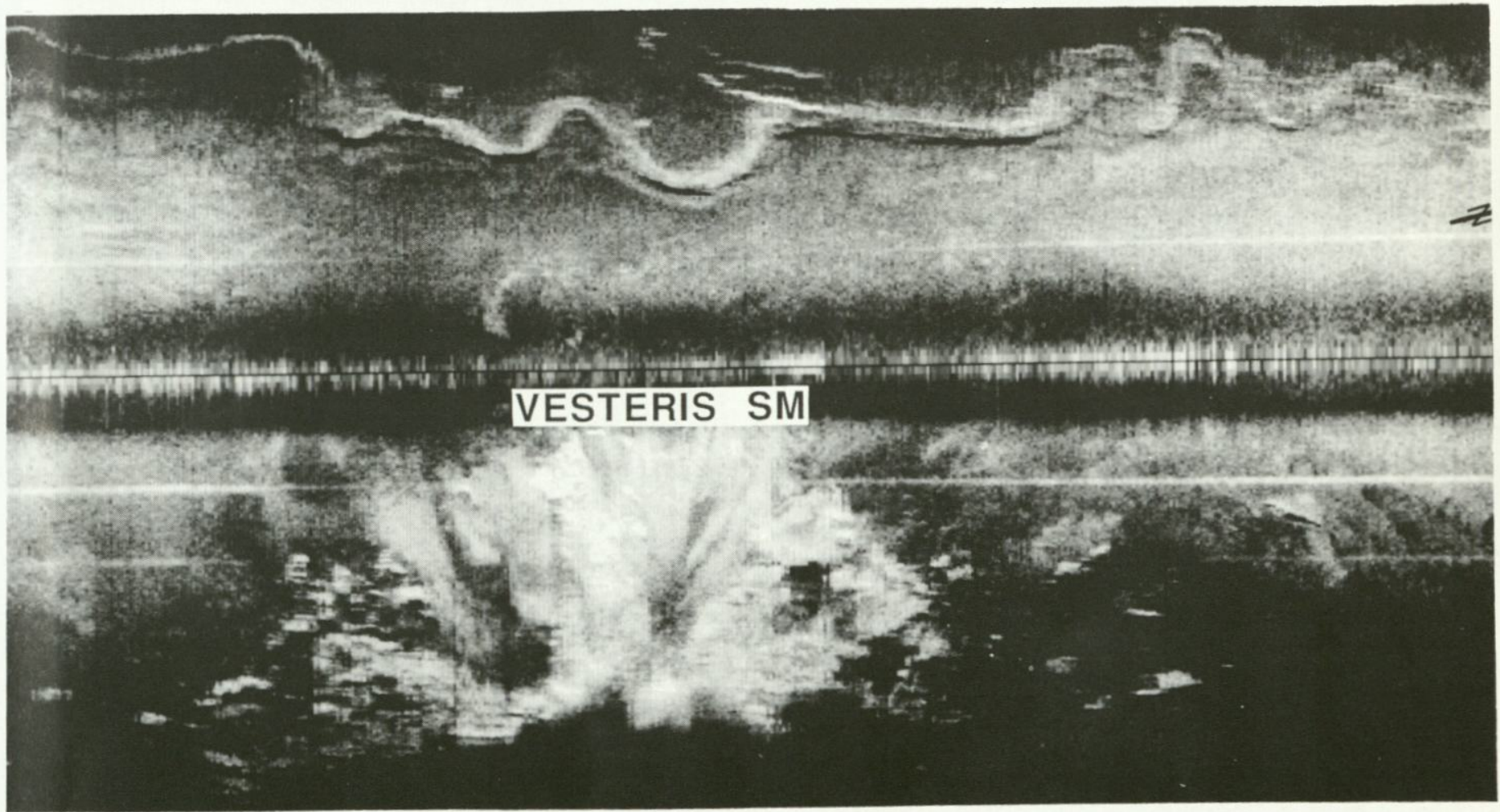

Fig. 3. Example of a GLORIA sonograph that shows the Vesteris Seamount (Figure 2) and a sinuous channel just northwest of it. The channel runs toward the northeast, the deepest part of the Greenland Basin. The horizontal and vertical scale (white) is approximately $10 \mathrm{~km}$. 
transport of sediments has been found along the east Greenland margin and basins

- in contrast, strong evidence exists for down-slope transport processes in the Greenland Basin

- sediment wave fields are indicative of the effects of bottom-water current or turbidity current activity at specific site locations

- circular high backscatter regions give hints of large areas of gas venting that need to be ground-truthed by coring and seismic studies, and

- a large contrast with the Norwegian margin exists in that the wide areas of sediment-slide complexes, a characteristic feature of the Norwegian margin, were not observed on the east Greenland margin, suggesting that the sediment stability of the two margins is different.

\section{Acknowledgments}

We thankfully acknowledge the Deutsche Forschungsgemeinschaft (Project B1, SFB 313, Christian-Albrechts-Universität, Kiel,
Germany) for funding this cooperative work and GEOMAR (Kiel, Germany) for financial support of ship time. We also thank P. Fox of the University of Rhode Island for his constructive comments and review of the manuscript.

\section{References}

Belderson, R. H., N. H. Kenyon, A. H. Stride, and C. D. Pelton, A braided distributary system on the Orinoco deep-sea fan, Mar. Geol., 56, 195, 1984.

Bugge, T., R. H. Belderson, and N. H. Kenyon, The Storegga Slide, Philos. Trans. R. Soc. London, Ser. A, 325, 357, 1988.

Hempel, P., R. Schreiber, L. Johnson, and J. Thiede, The Vesteris seamount (Greenland $\mathrm{Ba}$ sin): Patterns of morphology and sediment distribution, Mar. Geol., 96, 175, 1991.

Henrich, R., M. Hartmann, J. Reitner, P. Schaefer, A. Freiwald, S. Steinmetz, P. Dietrich, and J. Thiede, Facies belts and communities of the Arctic Vesterisbanken Seamount (Central Greenland Sea), Facies, 27, 71, 1992.

Huggett, Q. J., A. K. Cooper, M. L. Somers, and A. $\mathrm{R}$. Stubbs, Interference fringes on GLORIA side- scan sonar images from the Bering Sea and their implications, Mar. Geophys. Res., 14, 47, 1992.

Moerner, N.-A. The Fennoscandian uplift: Geologi$\mathrm{cal}$ data and their geodynamical implications, in Earth Rheology, Isostasy and Eustasy, edited by N.-A. Moerner, pp. 251-284, John Wiley \& Sons, New York, 1980

Ruddiman, W., and North Atlantic-Arctic Gateways Detailed Planning Group, North Atlantic Arctic gateways, Joides J., 17, 38, 1991.

Vogt, P. R., Seafloor topography, sediments, and paleoenvironments, in The Nordic Seas, edited by B. G. Hurdle, pp. 287-386, Springer, New York, 1986.

Vorren, T. O., E. Lebesbye, K. Andreassen, and K.-B. Larsen, Glacigenic sediments on a passive continental margin as exemplified by the Barents Sea, Mar. Geol., 85, 251, 1989. 